\title{
Response of Lactating Zaraibi Goats to Diets Containing Sesbania sesban Seeds as a New and High Source of Protein.
}

El-Kholany, M. E. ; G. A. Maged ; M. E. Ahmed ; A. M. Abdel-Gawad ; M. A. Aboul-Omran and A. A. Al-Mowafy.

Animal Production Research Institute, Agriculture Research Center, Dokki, Giza, Egypt.

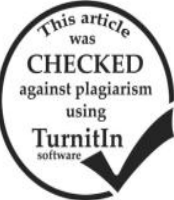

\section{ABSTRACT}

This work was carried out on dairy goats to investigate the effect of partially replacing CFM protein by Sesbania sesban seeds on milk production, feed conversion efficiency and some blood constituents as well as economic efficiency. Twenty five dairy goats were divided into 5 groups ( 5 does each). The control group $\left(\mathrm{G}_{1}\right)$ was fed a ration consisting of concentrate feed mixture and corn silage (50:50) according to NRC (1981) recommendation. Sesbania sesban seeds (SS) were used to replace 10 and $20 \%$ of concentrate's protein for groups $\mathrm{G}_{2}$ and $\mathrm{G}_{3}$, respectively. Sesbania seeds were treated (TSS) by soaking and roasting and used at the same levels (10 and $20 \%$ ) in $\mathrm{G}_{4}$ and $\mathrm{G}_{5}$, respectively. The feeding trails lasted for 14 weeks after weaning. The obtained results showed that the daily dry matter intake tended to decrease as a result to substitution of concentrate feed mixture with Sesbania seeds in rations of dairy goats. On the contrary, the daily water consumption as $\mathrm{ml} / \mathrm{g}$ DM intake was noticeably higher $(3.50,3.64,3.67$ and 3.81) with Sesbania seeds rations $\left(\mathrm{G}_{2}, \mathrm{G}_{3}, \mathrm{G}_{4}\right.$ and $\mathrm{G}_{5}$, respectively) compared with control $\left(\mathrm{G}_{1}, 3.14\right)$. The effect of the tested rations on ruminal $\mathrm{pH}$ values was not significant. Ruminal $\mathrm{NH}_{3}$ concentration post-feeding tended to decrease as a result to using of Sesbania seeds especially $\mathrm{G}_{4}$ and $\mathrm{G}_{5}$. But, ruminal total VFA's concentrations post-feeding were significantly with $\mathrm{G}_{4}$ compared with $\mathrm{G}_{1}$ and $\mathrm{G} 3$. Moreover, ruminal microbial protein content at 2 and $4 \mathrm{hrs}$. post-feeding was significantly affected as a result of using of Sesbania seeds in goats rations and the bestIvalue was recordedIwith $\mathrm{G}_{4}$.. The obtained results showed that there is significant effects on some blood parameters ( hemoglobin, $\mathrm{MCHC}$, lymphocyts, platelets count, globulin and enzymatic activites) due to using the tested rations. Concerning milk production, the obtained data indicated that the highest value of daily milk yield was recorded with $\mathrm{G}_{4}(1.70 \mathrm{~kg})$ followed by $\mathrm{G}_{5}(1.67 \mathrm{~kg})$ then $\mathrm{G}_{2}(1.59$ $\mathrm{kg})$ and $\mathrm{G}_{1}(1.56 \mathrm{~kg})$ while the lowest value $(1.499 \mathrm{~kg})$ was recorded with $\mathrm{G}_{3}$ and the differences were significant. The effects of experimental rations on milk constituents were not significant. The feed conversion efficiency, based on DM was better with $\mathrm{G}_{5}(0.904)$ then $\mathrm{G}_{4}(0.911)$ followed by $\mathrm{G}_{2}$ and $\mathrm{G}_{3}\left(0.971\right.$ and 1.009 , respectively) and lastly $\mathrm{G}_{1}(1.015)$. Therefore, the economic efficiency was improved by $9.25,10.17,16.31$ and $22.81 \%$ with Sesbania seeds rations $\left(\mathrm{G}_{2}, \mathrm{G}_{3}, \mathrm{G}_{4}\right.$, and $\mathrm{G}_{5}$, respectively) compared with control $\left(\mathrm{G}_{1}\right)$. It is concluded that partial replasment of up to $20 \%$ of CFM protein by Sesbania seeds has some positive effects on metabolic parameters, which reflected on the dairy goats performance and economic efficiency.

Keywords : Dairy Zaraibi goats- milk production- feed conversion - blood constituents - economic studies- rumen parameters.

\section{INTRODUCTION}

Seeds of the family leguminosae (e.g. pulses, feed legumes, dry beans) are important sources of protein, minerals, vitamins and energy in diets for farm animals (Van der Poel, 1990), Sesbania sesban is a legume shrub adapted to summer season and its plants can be successfully cultivated by seeds under irrigation (Abdl-Rahman et al. 1995). Many studies ( Hossain and Becker, 2001,Hossain et al. 2002 and Pugalenthi et al. 2004 indicated that the Sesbania seeds contain high level of crude protein ( 29 to $33 \%$ of DM). Thus, legumes such as Sesbania sesban seeds constitute an important feed stuff and are an economic source of protein in the diets as reported by Kummar et al. (1991) and Pugalenthi et al. (2004). In a recent study, ElKholany et al. (2013) studied the effect of feeding Sesbania seeds as a source of protein to partly replace the expensive CP of the concentrate feed mixture on growth performance of Zaraibi kids and they concluded that the Sesbania seeds could by safely, economically and successfully used as a source of feed protein for to replace up to $30 \%$ of CFM protein in kids rations since it did not have adverse effect on ruminal fermentation parameters, blood constituents and feeding values of rations compared with control. In another study, Hossain et al. (2002) studied the effect of different treatments such as soaking in water for 24h., soaking+ autoclaving at $121^{\circ} \mathrm{c}$ for $30 \mathrm{~min}$., autoclaving and dry heating $130^{\circ} \mathrm{c}$ for $1 \mathrm{~h}$ on solubility and various anti nutrients levels such as total phenols, tannins, phytic acid, saponin and trypsin inhibitor activity in different species of Sesbania seeds ( Sesbania aculeate, Sesbania rostorata, Sesbania sesban (accession 10865 D) and s. sesban (accession 15019 D) and the study indicated that the treatments such as soaking autoclaving was the most effective treatment for reducing the ant nutrient levels in different Sesbania seeds.

Therefore, the aim of this work was to evaluate the effect of using Sesbania sesban seeds (treated or untreated) to partially subistute CFM protein in rations of lactating Zaraibi goats on milk production, feed conversion and economic efficiency. Some rumen parameters and blood profile were also stated.

\section{MATERIALS AND METHODS}

This study was conducted at the Animal Production Research Station, El-Serw, belonging to Animal Production Research Institute, Agricultural Research Center, Egypt.

Twenty five Zaraibi does in the $2^{\text {nd }}, 3^{\text {rd }}$ and $4^{\text {th }}$ lactation seasons were selected from El-Serw Station herd, and weighing on average $35.88 \mathrm{~kg}$. The animals were divided according to their body weight into 5 similar groups (5 each), to study effect of using Sesbania seeds as a source of protein at levels of $0.0\left(\mathrm{G}_{1}\right)$, $10 \%\left(\mathrm{G}_{2}\right)$ and $20 \%\left(\mathrm{G}_{3}\right)$ from CFM protein. Sesbania seeds were treated by soaking and roasting according to Yilkal et al., (2014) (soaking in water to $24 \mathrm{hrs}$. and roasting in oven at $145 \mathrm{C}^{0} 24 \mathrm{hrs}$.) and used at the same levels 10 and $20 \%$ in $\mathrm{G}_{4}$ and $\mathrm{G}_{5}$, respectively. Each group was housed in a semi-roofed yard (4 $\times 3 \times 5$ meters). The animals were weighed at the beginning then biweekly. Zaraibi goats were fed for 2 weeks as a transitional period on the experimental rations before the start of the experimental work. Feeding the experimental rations lasted 14 weeks after weaning. The nutrients requirements were calculated according to NRC (1981) of dairy goats. The amount of concentrate feed mixture 
and corn silage were offered at 50:50 ratio as reported by Ahmed and El-Kholany (2012) on dairy goats. Animals were fed the assigned ingredients as mixed rations. The used concentrate feed mixture (CFM) contained: undecorticated cotton seed meal (25\%), yellow corn $(43 \%)$, wheat bran $(25 \%)$, molasses $(3.5 \%)$, limestone $(2 \%)$, common salt $(1 \%)$ and minerals mixture $(0,5 \%)$. The chemical composition of the tested ingredients was determined (Table 1), Water was available at all times and drinked water was measured for each group ( $\mathrm{ml} /$ day). Diets were offered twice daily at 8.0 am and 3.0 and pm any refused amounts were daily recorded. Proximate chemical analysis of the feeds was carried out according to A.O.A.C (1995).

Rumen fluid samples were taken from 3 animals of each experimental group using stomach tube before feeding ( 0 time) and at 2, 4 and $6 \mathrm{hrs}$ post -feeding at the end of feeding trails. The samples were filtered through 3 layers of gauze and $\mathrm{pH}$ was immediately determined by $\mathrm{pH}$ meter. Ammonia nitrogen $\left(\mathrm{NH}_{3}-\mathrm{N}\right)$ concentration was measured according to the method of Conway (1957). Microbial protein was determined according to Schultz and Schultz (1970), whereas total volatile fatty acids (VFAs) were determined according to the technique described by Warner (1964).

Milk yield was collected daily for each doe by hand milking twice daily. Representative milk samples (about $0.5 \%$ of total milk produced) were taken biweekly for each doe, at both milking. Composite samples were analyzed for contents of total solid (TS) and protein according to Ling procedures (1963).Fat content was determined by using lacto scan made in Bulgaria. Lactose was determined according to Parnett and Abd El-Tawab

Table 1. Chemical analysis of feed ingredients.

\begin{tabular}{|c|c|c|c|c|c|c|c|}
\hline \multirow{2}{*}{ Items } & \multirow{2}{*}{ DM } & \multicolumn{6}{|c|}{ Composition, \% DM basis } \\
\hline & & OM & $\mathbf{C P}$ & CF & EE & NFE & ASH \\
\hline Concentrate feed mixture, CFM & 91.05 & 93.95 & 15.00 & 15.93 & 3.35 & 59.67 & 6.05 \\
\hline Sesbania sesban seeds, SS & 92.9 & 96.35 & 30.65 & 7.50 & 5.41 & 52.79 & 3.65 \\
\hline Treated Sesbania sesban seeds, TSS & 93.15 & 96.71 & 31.17 & 7.25 & 5.29 & 53.0 & 3.29 \\
\hline Corn silage, $\mathrm{CS}$ & 35.00 & 91.71 & 9.00 & 29.50 & 3.21 & 50.00 & 8.29 \\
\hline \multicolumn{8}{|c|}{ Experimental rations : } \\
\hline$\overline{50 \% \mathrm{CFM}+50 \% \text { corn silage }(\mathrm{G} 1)}$ & 63.27 & 92.84 & 12.03 & 21.63 & 3.28 & 55.90 & 7.16 \\
\hline $46 \% \mathrm{CFM}+51 \%$ corn silage $+3 \% \mathrm{SS}(\mathrm{G} 2)$ & 62.42 & 92.87 & 12.33 & 22.54 & 3.34 & 54.66 & 7.13 \\
\hline $42 \% \mathrm{CFM}+52 \%$ corn silage $+6 \% \mathrm{SS}(\mathrm{G} 3)$ & 61.57 & 92.90 & 12.66 & 22.60 & 3.38 & 54.26 & 7.10 \\
\hline $46 \%$ CFM $+51 \%$ corn silage $+3 \%$ SS $(\mathrm{G} 4)$ & 62.54 & 92.88 & 12.34 & 22.63 & 3.33 & 54.58 & 7.12 \\
\hline $42 \%$ CFM $+52 \%$ corn silage $+6 \%$ SS (G5) & 61.76 & 92.73 & 12.68 & 22.60 & 3.37 & 54.08 & 7.27 \\
\hline
\end{tabular}

\section{Feed intake:}

The daily feed intake of lactating Zaraibi goats during mid-lactation are presented in Table 2. The total $\mathrm{DM}$ intake as $\mathrm{g} / \mathrm{kg} \mathrm{w}^{0.75}$ tended to decrease (109.2, 105.5 and 104.6) with increasing level of Sesbania sesban seeds $(0,10$ and $20 \%)$ in goats rations $\left(\mathrm{G}_{1}, \mathrm{G}_{2} \mathrm{G}_{3}\right.$, respectively). The same trend was observed with treated Sesbania seeds (TSS) in $\mathrm{G}_{4}$ and $\mathrm{G}_{5}$ (104.6 and $102.2 \mathrm{~g} / \mathrm{kg} \mathrm{w}^{0.75}$, respectively). The corresponding values of feed intake as $\%$ BW were 4.47, 4.30, 4.29, 4.26 and 4.17 for $\mathrm{G}_{1}, \mathrm{G}_{2}, \mathrm{G}_{3}$, $\mathrm{G}_{4}$ and $\mathrm{G}_{5}$, respectively. The clear decrease in DM intake as $\mathrm{g} / \mathrm{h}, \mathrm{g} / \mathrm{kgw}^{0.75}$, and $\% \mathrm{BW}$ with increasing level of Sesbania sesban even after being treated might indicate that some anti-nutritional factors remained in the seeds. The same trend was observed also by El-Kholany et al.
(1957). Ash content was determined as reported in A.O.A.C. (1984).

Blood samples were collected from the jugular vein once before feeding ( 3 animals in each) at the end of experimental period. Blood samples were centrifuged at $4000 \mathrm{rpm}$ for $20 \mathrm{~min}$. Part of the separated serum was directed to enzyme activity determination, while the other part was stored frozen at $-200 \mathrm{C}$ till the biochemical analysis. Commercial kits were used for colorimetric biochemical determination.

Data were statistically analyzed by one way analysis of variance using SAS (2003) programme. The significant differences among means were assigned according to Duncan (1955).

\section{RESULTS AND DISCUSSION}

\section{Chemical composition of Sesbania sesban seeds:}

The chemical composition of feed ingredients in Table1 indicated that Sesbania sesban seeds (SS) contained 92.9\% DM, 30.65\% CP, 7.50\% CF, 5.41\% EE, 52.79\% NFE and $3.65 \%$ ash. Similar results were observed with treated Sesbania seeds (TSS) as shown in Table1. The chemical composition obtained in this study is nearly similar to that obtained by Pugalenthi et al., (2004) and Hossain and Becker(2001) with different Sesbania seeds. In a recent study, El-Kholany et al. (2013) reported that Sesbania sesban seeds contained $31.19 \%$ CP, 5.30\% EE, $52.63 \%$ NFE, $7.31 \% \mathrm{CF}$ and $3.57 \%$ ash on DM basis. In the same year, Arekemase et al (2013) stated that Sesbania seeds were rich in all the essential nutrients such as protein, energy, minerals and vitamins. It is worth noting that Sesbania seeds contain almost double CP content than that of CFM and nearly 3 folds of CS. The reverse was true for CF contents.
(2013) with using of Sesbania sesban seeds in rations of growing Zaraibi kids. On the other hand, the obtained values of dry matter intake are within the normal range given by Ahmed and El-Kholany (2012) with lactating Zaraibi goats during the early-lactation period (ranged from 102 to 107 when related to metabolic body size or from 4.01 to $4.13 \%$ of BW).

\section{Water consumption:}

The average daily water consumption of lactating goats fed the tested experimental rations is summarized in Table 3 . The daily water consumption was noticeably affected as a result to using of Sesbania seeds in both untreated $\left(\mathrm{G}_{2}\right.$ and $\left.\mathrm{G}_{3}\right)$ and treated $\left(\mathrm{G}_{4}\right.$ and $\left.\mathrm{G}_{5}\right)$. The highest value of water consumption as $\mathrm{L} / \mathrm{head}, \mathrm{ml} / \mathrm{kg}$ $\mathrm{w}^{0.82}$ and $\mathrm{ml} / \mathrm{g} \mathrm{DM}$ intake was recorded with $\mathrm{G}_{5}(5.75$, 
303 and 3.81, respectively) then $\mathrm{G}_{4}(5.69,299$ and 3.67, respectively) whereas the lowest value $(4.99,267$ and 3.14 , respectively) was detected with control group $\left(\mathrm{G}_{1}\right)$. Thus, the water consumption was higher with increasing level of Sesbania seeds in rations of lactating Zaraibi does especially in both two TSS groups $\left(\mathrm{G}_{4}\right.$ and $\mathrm{G}_{5}$ ). This result indicates a direct relationship between voluntary water and milk yield in dairy goats as reported by Ahmed et al. (2001) and El-Kholany (2004) with using of (Kochia and Sesbania) in dairy goats rations. In this respect, El-Kholany et al. (2013) found that the values of water consumption as $\mathrm{ml} / \mathrm{g} \mathrm{DM}$ intake was higher $(3.11,3.21,3.34$ and 3.36) with increasing level of Sesbania seeds in goats rations $(0$, 10, 20 and $30 \%$, respectively).

Table 2. Average daily feed intake* by Zaraibi goats fed the experimental rations.

\begin{tabular}{lccccc}
\hline \multirow{2}{*}{ Items } & \multicolumn{5}{c}{ Groups } \\
\cline { 2 - 6 } & $\mathbf{G}_{\mathbf{1}}$ & $\mathbf{G}_{\mathbf{2}}$ & $\mathbf{G}_{\mathbf{3}}$ & $\mathbf{G}_{\mathbf{4}}$ & $\mathbf{G}_{\mathbf{5}}$ \\
\hline \multicolumn{5}{c}{ Daily feed intake, g DM /h : } \\
\hline Concentrate feed mixture & 801 & 721 & 641 & 721 & 641 \\
Sesbania Seeds & 0.00 & 39 & 78 & 38.5 & 77 \\
Corn Silage & 787 & 791 & 793 & 789 & 792 \\
Total DM intake & 1588 & 1551 & 15121548.5 & 1510 \\
DM intake, \%BW & 4.47 & 4.30 & 4.29 & 4.26 & 4.17 \\
DM intake, g/kg 0.75 & 109.2 & 105.3 & 104.6104 .6 & 102.2 \\
Roughage : concentrate (R/C) ratio & $50: 50$ & $51: 49$ & $52: 4851: 49$ & $52: 48$ \\
\hline *Group feeding & \multicolumn{5}{c}{}
\end{tabular}

Table 3. Daily water consumption* by lactating Zaraibi does as affected by experimental treatments.

\begin{tabular}{lccccc}
\hline \multirow{2}{*}{ Items } & \multicolumn{5}{c}{ Groups } \\
\cline { 2 - 6 } & $\mathbf{G}_{\mathbf{1}}$ & $\mathbf{G}_{\mathbf{2}}$ & $\mathbf{G}_{\mathbf{3}}$ & $\mathbf{G}_{\mathbf{4}}$ & $\mathbf{G}_{\mathbf{5}}$ \\
\hline \multicolumn{5}{c}{ Daily water consumption : } \\
\hline $\mathrm{L} / \mathrm{head} /$ day & 4.99 & 5.43 & 5.51 & 5.69 & 5.75 \\
$\mathrm{ml} / \mathrm{kg} \mathrm{BW}$ & 141 & 150 & 156 & 157 & 159 \\
$\mathrm{ml} / \mathrm{kg} \mathrm{W}^{0.75}$ & 343 & 367 & 381 & 384 & 389 \\
$\mathrm{ml} / \mathrm{kg} \mathrm{W}^{0.82}$ & 267 & 287 & 297 & 299 & 303 \\
$\mathrm{ml} / \mathrm{g} \mathrm{DM}$ intake & 3.14 & 3.50 & 3.64 & 3.67 & 3.81 \\
\hline${ }^{*}$ Group feeding & & & &
\end{tabular}

Generally, the values of daily water consumption in this study are nearly similar to those obtained by Ahmed and El-Kholany (2012) on lactating Zaraibi goats (ranged from 140 to $166 \% \mathrm{BW}$, from 372 to 441 $\mathrm{ml} / \mathrm{kgw}^{0.75}$ and from 3.85 to $4.81 \mathrm{ml} / \mathrm{g} \mathrm{DM}$ intake).

\section{Ruminal fluid parameters:}

Rumen fluid parameters as affects by dietary treatments are presented in Table 4 and 5. The minimum $\mathrm{pH}$ values and the maximum $\mathrm{NH} 3-\mathrm{N}$ values were recorded 4 hrs post-feeding as shown in Table (4). The same trend was obtained by Ahmed et al. (2001) and ElEmam et al. (2014), but, the effect of the tested experimental rations on both $\mathrm{pH}$ values and ammonia-N concentrations were not significant within each sampling time. However, ruminal NH3-N concentration post-feeding tended to decrease as result to using of Sesbania seeds especially G4 $(21.13,22$. and 20.40 $\mathrm{mg} / 100 \mathrm{ml}$ during 2, 4 and $6 \mathrm{hrs}$. , respectively). Moreover, the effect of using Sesbania seeds on ruminal total volatile fatty acids (VFA's) post-feeding were significant as shown in Table4. In the sametime, rumen total VFA's concentrations during the all hours postfeeding (2, 4 and $6 \mathrm{hrs}$.) were the highest with G4 $(11.23,12.0$ and $11.30 \mathrm{mEq} / 100 \mathrm{ml}$, respectively) while the lowest values were detected with G3 (10.50, 11.03 and $10.50 \mathrm{mEq} / 100 \mathrm{ml}$, respectively) and the differences were significant among intervals of sampling. Similarly, ruminal microbial protein was not significant different among five treatments at zero time and was significantly $(p<0.05)$ higher with G4 then G3 at 2 and 4 hrs. Postfeeding. The obtained data indicated also that the highest values of microbial protein $(0.350,0.587,0.593$ and $0.493 \mathrm{~g} / 100 \mathrm{ml})$ and lowest values of ruminal NH3$\mathrm{N}(17.07,21.13,22.0$ and $20.40 \mathrm{mg} / 100 \mathrm{ml})$ were recorded with G4 at all hours $(0,2,4$ and $6 \mathrm{hrs}$. respectively). The present findings are in agreement with those reported by El-Kholany et al. (2013). Who observed also some noticeable and positive effects in ruminal protein, total VFA's concentrations and proportions of individual VFA's\% as a result to using of Sesbania sesban seeds in rations of growing kids, whereas the differences in both ruminal $\mathrm{pH}$ value and $\mathrm{NH} 3-\mathrm{N}$ concentration were fewer values.

\section{Table 4. Effect of experimental rations on rumen fermentation parameters of dairy Zaraibi goats}

\begin{tabular}{|c|c|c|c|c|c|c|}
\hline \multirow{2}{*}{ tems } & \multirow{2}{*}{ Hours } & \multicolumn{5}{|c|}{ Groups } \\
\hline & & $\mathbf{G}_{1}$ & $\mathbf{G}_{2}$ & $\mathbf{G}_{3}$ & $\mathbf{G}_{4}$ & $\mathbf{G}_{\mathbf{5}}$ \\
\hline \multirow{4}{*}{$\mathrm{pH}$ values } & 0 & $7.13 \pm 0.03$ & $7.15 \pm 0.03$ & $7.10 \pm 0.07$ & $7.07 \pm 0.00$ & $7.08 \pm 0.11$ \\
\hline & 2 & $6.72 \pm 0.04$ & $6.70 \pm 0.06$ & $6.78 \pm 0.05$ & $6.68 \pm 0.03$ & $6.70 \pm 0.06$ \\
\hline & 4 & $6.57 \pm 0.06$ & $6.55 \pm 0.07$ & $6.60 \pm 0.05$ & $6.50 \pm 0.07$ & $6.53 \pm 0.04$ \\
\hline & 6 & $6.68 \pm 0.04$ & $6.70 \pm 0.06$ & $6.72 \pm 0.06$ & $6.61 \pm 0.05$ & $6.65 \pm 0.08$ \\
\hline \multirow{4}{*}{$\begin{array}{l}\mathrm{NH}_{3}-\mathrm{N} \\
(\mathrm{mg} / 100 \mathrm{ml})\end{array}$} & 0 & $18.33 \pm 0.36$ & $19.03 \pm 0.34$ & $17.93 \pm 0.28$ & $17.07 \pm 0.29$ & $18.40 \pm 0.31$ \\
\hline & 2 & $21.60 \pm 0.17$ & $22.27 \pm 0.45$ & $22.33 \pm 0.42$ & $21.13 \pm 0.35$ & $21.30 \pm 0.44$ \\
\hline & 4 & $22.47 \pm 0.47$ & $23.00 \pm 0.40$ & $23.40 \pm 0.41$ & $22.00 \pm 0.20$ & $22.33 \pm 0.53$ \\
\hline & 6 & $20.73 \pm 0.47$ & $21.47 \pm 0.44$ & $21.73 \pm 0.47$ & $20.40 \pm 0.41$ & $20.60 \pm 0.45$ \\
\hline \multirow{4}{*}{$\begin{array}{l}\text { Total VFA's (m Eq } \\
/ 100 \mathrm{ml})\end{array}$} & 0 & $9.10 \pm 0.28$ & $9.07 \pm 0.25$ & $8.90 \pm 0.27$ & $9.13 \pm 0.29$ & $9.10 \pm 0.28$ \\
\hline & 2 & $10.67 \pm 0.16^{\mathrm{b}}$ & $10.73 \pm 0.17^{\mathrm{b}}$ & $10.50 \pm 0.15^{\mathrm{b}}$ & $11.23 \pm 0.19^{\mathrm{a}}$ & $10.87 \pm 0.17^{\mathrm{ab}}$ \\
\hline & 4 & $11.23 \pm 0.17^{\mathrm{c}}$ & $11.37 \pm 0.19^{c}$ & $11.03 \pm 0.03^{\mathrm{c}}$ & $12.00 \pm 0.12^{\mathrm{ab}}$ & $11.63 \pm 0.10^{\mathrm{bc}}$ \\
\hline & 6 & $11.00 \pm 0.01^{\mathrm{b}}$ & $11.03 \pm 0.02^{b}$ & $10.50 \pm 0.09^{c}$ & $11.30 \pm 0.14^{\mathrm{a}}$ & $11.10 \pm 0.12^{\mathrm{ab}}$ \\
\hline \multirow{4}{*}{$\begin{array}{l}\text { Microbial protein }(\mathrm{g} / \\
100 \mathrm{ml})\end{array}$} & 0 & $0.343 \pm 0.01$ & $0.330 \pm 0.001$ & $0.323 \pm 0.007$ & $0.350 \pm 0.300$ & $0.330 \pm 0.010$ \\
\hline & 2 & $0.560 \pm 0.009^{b c}$ & $0.567 \pm 0.007^{\mathrm{bc}}$ & $0.540 \pm 0.010^{c}$ & $0.587 \pm 0.007^{\mathrm{a}}$ & $0.570 \pm 0.007^{\mathrm{ab}}$ \\
\hline & 4 & $0.567 \pm 0.10^{\mathrm{bc}}$ & $0.570 \pm 0.007^{\mathrm{bc}}$ & $0.533 \pm 0.007^{\mathrm{c}}$ & $0.593 \pm 0.009^{\mathrm{a}}$ & $0.577 \pm 0.009^{\mathrm{ab}}$ \\
\hline & 6 & $0.453 \pm 0.007$ & $0.460 \pm 0.008$ & $0.440 \pm 0.010$ & $0.493 \pm 0.009$ & $0.473 \pm 0009$ \\
\hline
\end{tabular}

Means in the same row with different superscripts differ significantly at $\mathbf{P}<0.05$. 


\section{Blood profile:}

Data of hematological parameters of lactating Zaraibi does fed different experimental rations during midlactation period are presents in Table 5. The obtained data indicated that most hematological parameters were not markedly affect by the tested experimental rations. But, the effect of using Sesbania seeds on both hemoglobin $(\mathrm{Hb})$ and mean cell hemoglobin concentration (MCHC) were significant. Moreover, the highest values of lymphocytes and platelets counts were recorded with G4 (54.85, 427, respectively) whereas the lowest values were detected with control group (49.9 and 385, respectively) and the differences were significant. In the sametime, the values of $\mathrm{MCV}$ and MCH were also higher with G4 (22.85 and 8.81, respectively) than other groups but without significance differences. Similar results were observed by El-Kholany et al. (2013) with using Sesbania sesban seeds (at levels 10, 20 and $30 \%$ ) in kids rations.

Data of biochemical parameters of dairy Zaraibi goats fed tested experimental rations are presented in
Table 6. Values of some serum blood parameters explained that there were no significant differences among the five rations for glucose, albumin, creatinine, urea, triglyceride, cholesterol, calcium, phosphorus and manganese, while serum total protein of control group was significantly decrease than G4 and G5. In the same line, the highest value of globulin was recorded with G4 (3.53) then G5 (3.45) followed by G2 and G3 (3.41 and 3.31 , respectively) and the lowest value (3.12) was detected with G1 (control group) and the difference were significant. The obtained results indicated also that activities of serum AST and ALT decreased with using Sesbania sesban in goats rations and the significant effect was clear in G4 and G5 (TSS) only. The obtained values are within the normal range reported by Jain (1986) (for hematological parameters) and Kaneko (1989) (for biochemical parameters) for healthy goats and in line with the finding of El-Kholany et al. (2013) when they used Sesbania seeds in kids ration.

Table 5. Effect of experimental treatments on blood hematological parameters of lactating Zaraibi goats

\begin{tabular}{lccccc}
\hline \multirow{2}{*}{ Items } & \multicolumn{3}{c}{ Groups } \\
\cline { 2 - 6 } & $\mathbf{G}_{\mathbf{1}}$ & $\mathbf{G}_{\mathbf{2}}$ & $\mathbf{G}_{\mathbf{3}}$ & $\mathbf{G}_{\mathbf{4}}$ & $\mathbf{G}_{\mathbf{5}}$ \\
\hline Hemoglobin $(\mathrm{Hb}), \mathrm{g} / \mathrm{dl}$ & $10.80 \pm 0.19^{\mathrm{b}}$ & $11.50 \pm 0.21^{\mathrm{ab}}$ & $11.03 \pm 0.19^{\mathrm{b}}$ & $11.85 \pm 0.20^{\mathrm{a}} 11.65 \pm 0.10^{\mathrm{ab}}$ \\
Red blood cell (RBC's) $\times 10^{6} / \mathrm{ul}$ & $12.50 \pm 0.13$ & $12.70 \pm 0.13$ & $12.35 \pm 0.25$ & $13.05 \pm 0.30$ & $12.87 \pm 0.19$ \\
Hematocrit (Hct), \% & $34.20 \pm 0.63$ & $33.51 \pm 0.55$ & $35.05 \pm 0.49$ & $33.10 \pm 0.71$ & $34.07 \pm 0.63$ \\
Cell hemoglobin conc.(MCHC), \% & $31.60 \pm 0.51^{\mathrm{b}}$ & $34.27 \pm 0.47^{\mathrm{ab}}$ & $31.40 \pm 0.35^{\mathrm{b}}$ & $35.80 \pm 0.63^{\mathrm{a}} 34.20 \pm 0.38^{\mathrm{ab}}$ \\
Cell value (MCV), fl & $21.15 \pm 0.22$ & $22.0 \pm 0.40$ & $21.30 \pm 0.75$ & $22.85 \pm 0.80$ & $22.43 \pm 0.51$ \\
Cell hemoglobin (MCH),pg & $8.05 \pm 0.30$ & $8.21 \pm 1.05$ & $7.93 \pm 0.83$ & $8.81 \pm 0.61$ & $8.45 \pm 0.29$ \\
T. Leucocytic count, x10 ${ }^{3} / \mathrm{ul}$ & $13.55 \pm 0.55$ & $13.41 \pm 0.79$ & $13.81 \pm 0.43$ & $12.50 \pm 0.95$ & $13.20 \pm 0.79$ \\
Neutrophils, \% & $45.5 \pm 1.31$ & $41.89 \pm 1.15$ & $43.65 \pm 0.95$ & $41.30 \pm 0.79$ & $42.03 \pm 1.11$ \\
Lymphocytes, \% & $49.9 \pm 0.89^{\mathrm{b}}$ & $53.70 \pm 1.23^{\mathrm{a}}$ & $51.89 \pm 0.93^{\mathrm{ab}}$ & $54.85 \pm 1.21^{\mathrm{a}} 54.15 \pm 0.73^{\mathrm{a}}$ \\
Monocytes, \% & $2.85 \pm 0.43$ & $2.73 \pm 0.23$ & $2.51 \pm 0.29$ & $2.29 \pm 0.33$ & $2.52 \pm 0.21$ \\
Eosinophil's, \% & $1.75 \pm 0.33$ & $1.68 \pm 0.33$ & $1.95 \pm 0.33$ & $1.56 \pm 0.33$ & $1.30 \pm 0.33$ \\
Platelets count, $\mathrm{x} 10^{3} / \mathrm{ul}$ & $385 \pm 11.8^{\mathrm{b}}$ & $413 \pm 15.7^{\mathrm{ab}}$ & $397 \pm 19.3^{\mathrm{ab}}$ & $427 \pm 9.9^{\mathrm{a}}$ & $415 \pm 10.7^{\mathrm{ab}}$ \\
\hline
\end{tabular}

Means in the same row with different superscripts differ significantly at $P<0.05$.

Table 6. Effect of experimental treatments on serum biochemical parameters of lactating Zaraibi goats.

\begin{tabular}{lccccc}
\hline \multirow{2}{*}{ Items } & \multicolumn{4}{c}{ Groups } \\
\cline { 2 - 6 } & $\mathbf{G}_{\mathbf{1}}$ & $\mathbf{G}_{\mathbf{2}}$ & $\mathbf{G}_{\mathbf{3}}$ & $\mathbf{G}_{\mathbf{4}}$ & $\mathbf{G}_{\mathbf{5}}$ \\
\hline Glucose, mg/dl & $59.40 \pm 1.0$ & $61.26 \pm 1.25$ & $60.03 \pm 1.18$ & $62.71 \pm 1.31$ & $63.09 \pm 0.95$ \\
Total protein, g/dl & $6.70 \pm 0.31^{\mathrm{b}}$ & $6.90 \pm 0.25^{\mathrm{ab}}$ & $6.89 \pm 0.31^{\mathrm{ab}}$ & $7.33 \pm 0.19^{\mathrm{a}}$ & $7.15 \pm 0.45^{\mathrm{a}}$ \\
Albumin, g/dl & $3.58 \pm 0.25$ & $3.50 \pm 0.13$ & $3.56 \pm 0.21$ & $3.80 \pm 0.13$ & $3.71 \pm 0.10$ \\
Globulin, g/dl & $3.12 \pm 0.09^{\mathrm{b}}$ & $3.41 \pm 0.08^{\mathrm{a}}$ & $3.31 \pm 0.05^{\mathrm{ab}}$ & $3.53 \pm 0.11^{\mathrm{a}}$ & $3.45 \pm 0.09^{\mathrm{a}}$ \\
Creatinine, mg/dl & $0.99 \pm 0.07$ & $0.95 \pm 0.09$ & $0.97 \pm 0.08$ & $0.87 \pm 0.05$ & $0.91 \pm 0.03$ \\
Urea, mg/dl & $55.30 \pm 1.25$ & $53.90 \pm 1.22$ & $54.70 \pm 1.50$ & $52.35 \pm 1.15$ & $53.05 \pm 2.15$ \\
Triglyceride, ml/dl & $62.25 \pm 2.08$ & $59.85 \pm 1.15$ & $63.05 \pm 1.63$ & $59.03 \pm 1.20$ & $61.05 \pm 1.17$ \\
Cholesterol, mg/dl & $53.96 \pm 1.91$ & $52.13 \pm 1.17$ & $55.21 \pm 1.51$ & $51.59 \pm 1.35$ & $52.01 \pm 1.22$ \\
AST, ul & $94.61 \pm 2.11^{\mathrm{b}}$ & $89.15 \pm 1.61^{\mathrm{ab}}$ & $90.07 \pm 1.85^{\text {ab }}$ & $87.21 \pm 2.07^{\mathrm{a}}$ & $86.90 \pm 1.75^{\mathrm{a}}$ \\
ALT, ul & $22.95 \pm 1.05^{\mathrm{a}}$ & $21.15 \pm 0.71 .^{\mathrm{ab}}$ & $22.03 \pm 0.87^{\mathrm{ab}}$ & $20.25 \pm 0.65^{\mathrm{b}}$ & $20.50 \pm 1.0^{\mathrm{b}}$ \\
Calcium, mg/dl & $10.58 \pm 0.47$ & $10.81 \pm 0.51$ & $10.60 \pm 0.49$ & $10.75 \pm 0.61$ & $10.67 \pm 0.55$ \\
Phosphorus (inorganic) mg/dl & $5.40 \pm 0.20$ & $5.55 \pm 0.13$ & $5.29 \pm 0.21$ & $5.45 \pm 0.17$ & $5.35 \pm 0.09$ \\
Manganese, mg/dl & $2.81 \pm 0.17$ & $2.85 \pm 0.11$ & $2.70 \pm 0.13$ & $2.91 \pm 0.07$ & $2.75 \pm 0.08$ \\
\hline
\end{tabular}

Means in the same row with different superscripts differ significantly at $\mathrm{P}<0.05$.

\section{Milk yield and its composition:}

Data presented in Table7 show average daily milk yield and its composition for the five treatments. The differences in daily milk yield were significant $(\mathrm{p}<$ 0.05 ) among the tested experimental rations. The average milk yield had the highest values with G4 (1.70 $\mathrm{kg} / \mathrm{h} / \mathrm{d})$ followed by G5 $(1.670 \mathrm{~kg} / \mathrm{h} / \mathrm{d})$ then $\mathrm{G} 2(1.598$ $\mathrm{kg} / \mathrm{h} / \mathrm{d})$ and the lowest value $(1.499 \mathrm{~kg} / \mathrm{h} / \mathrm{d})$ was recorded with G3. This positive effect of treatment by Sesbania seeds especially in G4 and G5 (TSS) on milk yield by Zaraibi goats was observed also in yields of fat and protein as shown in Table 7 . These results were related to the metabolic parameters (rumen and blood) as reported earlier. 
As regard to milk composition (Table 7), the obtained results indicated that the effect of tested experimental rations on milk composition as fat, protein, total solids, solids non fat (SNF), lactose and ash fluctuated. However, the differences of milk content among the five groups were not significant $(\mathrm{P}<0.05)$ and the obtained values of milk constituents were within the normal range given by Ahmed (1999), El-Kholany (2004), Shehata et al. (2006) and Ahmed et al. (2013) for goats milk

Table 7. Effect of experimental rations on average milk yield, its composition and yield of fat and protein of lactating Zaraibi goats.

\begin{tabular}{lccccc}
\hline Items & \multicolumn{5}{c}{ Groups } \\
& G1 & G2 & G3 & G4 & G5 \\
\hline Average milk yield, kg/h/d & $1.564 \pm 0.03^{\mathrm{ab}}$ & $1.598 \pm 0.05^{\mathrm{ab}}$ & $1.499 \pm 0.07^{\mathrm{b}}$ & $1.700 \pm 0.02^{\mathrm{a}}$ & $1.670 \pm 0.02^{\mathrm{ab}}$ \\
\hline \multicolumn{5}{c}{ Milk composition : } \\
\hline Fat, \% & $3.78 \pm 0.09$ & $3.66 \pm 0.04$ & $3.80 \pm 0.08$ & $3.60 \pm 0.07$ & $3.62 \pm 0.07$ \\
Protein, \% & $2.88 \pm 0.03$ & $2.90 \pm 0.03$ & $2.91 \pm 0.03$ & $2.87 \pm 0.04$ & $2.86 \pm 0.04$ \\
Lactose, \% & $4.66 \pm 0.04$ & $4.67 \pm 0.04$ & $4.70 \pm 0.03$ & $4.64 \pm 0.03$ & $4.62 \pm 0.03$ \\
Total solids, \% & $12.04 \pm 0.09$ & $11.94 \pm 0.07$ & $12.14 \pm 0.09$ & $11.81 \pm 0.05$ & $11.81 \pm 0.05$ \\
Solids non fat, (SNF), \% & $8.26 \pm 0.06$ & $8.28 \pm 0.08$ & $8.34 \pm 0.07$ & $8.21 \pm 0.04$ & $8.20 \pm 0.04$ \\
Ash, \% & $0.72 \pm 0.005$ & $0.71 \pm 0.003$ & $0.73 \pm 0.005$ & $0.70 \pm 0.003$ & $0.71 \pm 0.003$ \\
Average fat yield, g/h/d & $591 \pm 24.20$ & $584 \pm 25.16$ & $565 \pm 21.12$ & $612 \pm 12.21$ & $604 \pm 15.30$ \\
Average protein yield, g/h/d & $450 \pm 13.82^{\mathrm{b}}$ & $463 \pm 12.20^{\mathrm{bc}}$ & $433 \pm 11.30^{\mathrm{b}}$ & $487 \pm 28.06^{\mathrm{ac}}$ & $477 \pm 27.35^{\mathrm{bc}}$ \\
\hline
\end{tabular}

Means in the same row with different superscripts differ significantly at $\mathrm{P}<0.05$.

\section{Feed conversion:}

The feed conversion efficiency based on dry matter and crude protein intake by lactating Zaraibi goats are summarized in Table 8 . The obtained results indicated that feed conversion calculated as dry matter intake/ milk yield was better with $\mathrm{G}_{5}(0.904)$ then $\mathrm{G}_{4}$ (0.911) followed by $\mathrm{G}_{2}$ and $\mathrm{G}_{3}$ (0.971 and 1.009, respectively) and lastly $G_{1}$ (1.015). Similarly, the values of feed conversion based on crude protein were better with two TSS groups $\left(\mathrm{G}_{4}\right.$ and $\left.\mathrm{G}_{5}\right)$ compared with other groups as shown in Table 8. In this respect, El-Kholany et al. (2013) stated the effect of using Sesbania seeds at levels $0,10,20$ and $30 \%$ in goats rations $\left(G_{1}, G_{2}, G_{3}\right.$, and $\mathrm{G}_{4}$, respectively) during growing period and found that the values of feed conversion expressed as TDN intake/ $\mathrm{kg}$ gain was better in kids received SS diets (5.81, 5.77 and 5.82 for $\mathrm{G}_{2}, \mathrm{G}_{3}$ and $\mathrm{G}_{4}$, respectively) compared with control $\left(\mathrm{G}_{1}, 5.97\right)$. The same trend was noticed also when efficiency of conversion was based on DM and DCP. However, the obtained values of feed conversion are within the normal range given by Shehata et al. (2006), Ahmed et al. 2013 and Ayyad et al. 2014 for dairy Zaraibi goats. In a recent study, ElEmam et al. (2014) found that the values of feed conversion (based on DM) ranged from 0.901 to 1.01 vs. from 0.123 to 0.145 when efficiency of conversion was based on CP.

Table 8. Feed utilization efficiency by lactating Zaraibi does as affected by the experimental rations.

\begin{tabular}{|c|c|c|c|c|c|}
\hline \multirow{2}{*}{ Items } & \multicolumn{5}{|c|}{ Groups } \\
\hline & $\mathbf{G}_{1}$ & $\mathbf{G}_{2}$ & $\mathbf{G}_{3}$ & $\mathbf{G}_{4}$ & $\mathbf{G}_{\mathbf{5}}$ \\
\hline No. of does & 5 & 5 & 5 & 5 & 5 \\
\hline Average body weight, kg: & 35.50 & 36.10 & 35.21 & 36.35 & 36.23 \\
\hline Metabolic body size, $\mathrm{w}^{0.75}$ & 14.54 & 14.73 & 14.45 & 14.80 & 14.77 \\
\hline \multicolumn{6}{|c|}{ Daily DM intake *during the experimental periods, $\mathrm{g} / \mathrm{h}$ : } \\
\hline Concentrate feed mixture & 801 & 721 & 641 & 721 & 641 \\
\hline Sesbania sesban & $0.00-$ & 39 & 78 & 38.5 & 77 \\
\hline Silage & 787 & 791 & 793 & 789 & 792 \\
\hline Total DM intake, $\mathrm{g} / \mathrm{h} / \mathrm{d}$ & 1588 & 1551 & 1512 & 1548.5 & 1510 \\
\hline $\mathrm{CP}$ intake, $\mathrm{g} / \mathrm{hd}$ & 191.0 & 191.3 & 191.4 & 191.2 & 191.4 \\
\hline Daily milk yield, $\mathrm{g} / \mathrm{h}$ & 1564 & 1598 & 1499 & 1700 & 1670 \\
\hline \multicolumn{6}{|l|}{ Feed utilization efficiency: } \\
\hline Kg DM / Kg milk & 1.015 & 0.971 & 1.009 & 0.911 & 0.904 \\
\hline Kg CP / Kg milk & 0.122 & 0.120 & 0.128 & 0.112 & 0.115 \\
\hline
\end{tabular}

*Group feeding

Economic efficiency:

Data in Table 9 indicated that the highest total feed cost $(\mathrm{LE} / \mathrm{h})$ along the feeding period was observed for $\mathrm{G}_{1}$ (3.314) compared with other groups (3.099, $2.882,3.096$ and 2.880 for $\mathrm{G}_{2}, \mathrm{G}_{3}, \mathrm{G}_{4}$ and $\mathrm{G}_{5}$, respectively). The corresponding values of price of milk yield were 4.692, 4.794, 4.497, 5.100 and 5.010 LE /h for $G_{1}, G_{2}, G_{3}, G_{4}$ and $G_{5}$, respectively). Therefore, the highest total feed cost/ $\mathrm{kg}$ milk (LE) was observed for
$\mathrm{G}_{1}$ (2.119) while the intermediate values were recorded for $G_{2}$ and $G_{3}$ (1.939 and 1.923, respectively) and the lowest values were for $G_{4}$ and $G_{5}$ (1.821 and 1.725, respectively), due to the highest daily milk yield as well as the lowest price of feed consumption in the two groups $\left(\mathrm{G}_{4}\right.$ and $\left.\mathrm{G}_{5}\right)$. Economic efficiency values revealed that $\mathrm{G}_{5}$ had the highest economic feed efficiency, followed by $G_{4}$ then $G_{3}$ and $G_{2}$ and lastly $G_{1}$. Thus, the economic return was clearly increased $(9.25,10.17$, 
16.31 and $22.81 \%)$ with Sesbania seeds rations $\left(\mathrm{G}_{2}, \mathrm{G}_{3}\right.$, $\mathrm{G}_{4}$ and $\mathrm{G}_{5}$, respectively) compared with control $\left(\mathrm{G}_{1}\right)$. This positive effect of Sesbania seeds (SS) on economic efficiency was observed by El-Kholany et al. (2013). They found that the economic efficiency was improved by about $9.0,12.0$ and $17.0 \%$ as a result to using of SS at level 10, 20 and 30\%, respectively in diets of growing male Zaraibi goats (kids).

Table 9. The effect of using Sesbania sesban seeds in dairy goats rations on economic efficiency.

\begin{tabular}{lccccc}
\hline \multirow{2}{*}{ Items } & \multicolumn{5}{c}{ Groups } \\
\cline { 2 - 6 } & G1 & G2 & G3 & G4 & G5 \\
\hline Concentrate feed mixture & Daily feed intake $(\mathrm{g} / \mathrm{h})$ as fed : \\
Sesbania sesban seeds & 880 & 792 & 704 & 792 & 704 \\
Corn silage & --- & 42.0 & 84.0 & 41.3 & 82.7 \\
Cost of consumed feed, LE/h & 2249 & 2260 & 2266 & 2254 & 2263 \\
Price of milk yield, LE/h & 3.314 & 3.099 & 2.882 & 3.096 & 2.880 \\
Feed cost/kg milk, LE & 4.692 & 4.794 & 4.497 & 5.100 & 5.010 \\
Economic efficiency, \% & 2.119 & 1.939 & 1.923 & 1.821 & 1.725 \\
\hline
\end{tabular}

\section{CONCLUSION}

It is concluded that the using Sesbania seeds to partially substitute CFM protein in rations of lactating goats had positive effects on metabolism, blood picture and globulin with clear decrease in enzymatic activities (AST, ALT), that was reflected on the dairy goats performance and health which lead to improving the milk production and feed conversion rate to milk. So, the use of Sesbania seeds to replace up to $20 \%$ of CFM has a great effect on the economics of milk production of dairy goats.

\section{REFERENCES}

A.O.A.C. (1984). Association of official analytical chemists METHODS OF Analysis $14^{\text {th }}$ Ed., Washington, DC.

A. O. A. C. (1995). Official Methods of Analysis. (16th) Edt. Association Analytical Chemists, Washington, D.C., USA. Abdl-Rahman, K. M., A. A. Kandil, S. El-Kasshab and S. Al-Deeb (1995). Chemical and nutritional studies on some forage shrubs adapted in arid region. J. Agric. Mansoura Univ., 20 (8) : 3669-3645.

Ahmed, M.E. (1999). Improving feed conversion efficiency during reproductive-stress. Ph. D. Thesis, Fac. Agric. Mansoura Univ.

Ahmed, M. E.; A.M. Abdelhamid, F.F. AbouAmou, E.S. Soliman, N.M. El-Kholy and E.I. Shehata (2001).Response of milk production of Zaraibi goats to feeding silage containing different levels of teosinte and kochia.Egyptian J. Nutrition and Feeds, 4 (Special Issue):141.

Ahmed, M. E. and M.E. El-Kholany (2012). Productive performance, some rumen parameters and blood profile of Zaraibi goats fed rations supplemented with chufa tubers during late pregnancy and suckling periods. J. Animal and Poultry Prod., Mansoura Univ., 3 (12): 537 - 555.

Ahmed M.E., E.I. Shehata, M. E. El-Kholany, G.I. ElEmam, E.I. Khalifa and H. Bahery (2013).Productive performance of Zaraibi goats fed berseem and/or triticale silage. The 4thScientific Conference of Animal Production Research Institute, 184:192.
Abdl-Rahman, K.M., Kandil, S. El-Kashab and S. Al-Deeb (1995). Chemical and nutritional studies on some forage shrubs adapted in arid region. J. Agric. Mansoura Univ., 20 (8): 3669-3675.

Arekemase S. O., I. Abdulwaliyu, M. A. Dakare, S. Bala, A. S. Ibraheem and O. L. Nkeonye. (2013). Quantitative evaluation of the nutritional constituents of Sesbania sesban seeds and pods. International Journal of Modern Plant \& Animal Sciences, 1(1): 16-27

Ayyad, K. M., W.M.A. Sadek, G.A. Maged, E.I. Shehata and M.E. Ahmed (2014). Impact of feeding microbial additives on production and hygienic quality in milk of Zaraibi does. 12th Conf. Agric. Dev. Res., Fac. Agric. Ain Shams Univ. Cairo, Egypt.

Conway, E.F.(1957). Micro diffusion Analysis and Volumetric Error. Rev. Ed. Lock Wood, London.

Duncan, D. (1955). Multiple ranges and multiple F-test. Biometrics, 11: 1 .

El-Emam G. I., Y.H. Hafez, H. Bahery, E.I. Khalifa, E. I. Shehata and M. E. Ahmed (2014). Growth performance and some rumen and blood parameters of growing Rahmani lambs fed diets containing Triticale and berseem silages and their mixture. Egyptian J. Sheep and Goat Sci., 9(1) :67-76.

El-Kholany, M. M (2004).Evaluation of some new green fodder for Farm animals.Ph.D. Thesis Fac. of Agric, Mansoura Univ.

El-Kholany, M. E., E. S. Soliman, F. A. El-Sayed, and M. E. Ahmed (2013) Growth performance, some rumen parameters and blood profile of male Zaraibi goats fed diets containing Sesbania sesban seeds as a new source of protein. . Animal and Poultry Prod., Mansoura Univ., 4 (12):747-759.

Hossain M. A. and Becker K. (2001).Nutritive value and nutritive factors in different verities of Sesbania seeds and their morphological factors. Food Chem., 73: 421-431.

Hossain MA, Focken U, Becker K (2002) Nutritional evaluation of dhaincha (Sesbania aculeata) seeds as dietary protein source for tilapia Oreochromisniloticus. Aquacult Res 33(9):653-662

Jain, N. C.(1986). Veterinary Hematology $4^{\text {th }}$ Ed., Lea. and Febiger. Philadelphia. 


\section{J. Animal and Poultry Prod.., Mansoura Univ., Vol. 7 (12), December, 2016}

Kaneko, J. J. (1989). Clinical Biochemistry of Animals. $4^{\text {th }}$ Ed., Academic Press, Inc. USA

Kummar, s. Singh, G. K., Kummar, R. Bahatia. N. K. and Awasthi, C.P. (1991) Variation in quality triets of pigon pea cajanuscagan L. M., (SP) varieties. J. of Feed Sci. Techn., 28: 173-174.

Ling, E.R. (1963). A Text Book of Dairy Chemistry.3rd Ed. Chapman and Hall Ltd., London.

NRC (1981).Nutrient Requirements of Domestic Animals. Nutrient Requirements of Goats.National Research Council, Washington, D.C. USA, of Official Analytical Chemists, Washington, D.C., USA.

Parnett, A.J.G. and G. Abd El-Tawab.(1957). Determination of lactose in milk and cheese.J.Sci Food Agric., 8: 437 - 441.

Pugalenthi, M. V. Vadivel, P. Gurumoorthi and K. Janardhanan (2004).Comparative nutritional evaluation of little known legumes, Tamarindusindica, Erythrimaindica and Sesbania bispinosa.Tropical and Sub Tropical Agroecosytems. (4) : 107-123.

SAS (2003).SAS. ISTATR User Guid: Statistics. Ver. 9.1; Fourt "Edition SAS Institute Inc; Cary; Nc. USA.
Schultz, T.A. and E. Schultz (1970).Estimation of rumen microbial nitrogen by three analytical methods. J. Dairy Sci., 53: 781.

Shehata, E.I., M.E. Ahmed, Faten. F. AbouAmmou, A.A. M. Soliman, K.M. Aiad and A.M. AbdelGawad (2006).Comparison of feeding reed as hay or silage with feeding berseem hay or Maize silage to dairy Zaraibi goats. Egyptian Sheep Goats and Desert Animals Sci., 1(1): 233-247.

Van der Poel, A. F. B., (1990). Effect of processing on anti nutritional factors and protein nutritional value of dry beans ( Phaseolusvulgares L.). A review Anim. Feed Sci. Techn.29, 179- 208.

Warner, A.C.I. (1964). Production of volatile fatty acids in the rumen, methods of measurements. Nutr.Abst.\& Rev., 34: 339.

Yilkal T., M. Yuseph and T. Firew (2014) Suplemintation with different forms of processed lupin ( Lupinusalbus ) grain in hay based feeding of washera sheep: Effect on feed intake, dogestabilty body weight and carcass parameters. Journal of Biology, Agric. and Healthcare. 4, 27 .

\section{مدي استجابة الماعز الزرايبي الحلاب للعلائق التي تحتوي بذور السيسبان كمصدر جليد ومرتفع في نسبة البروتين.

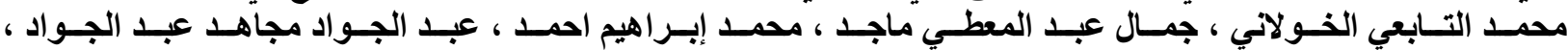

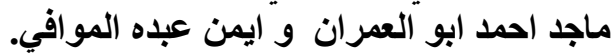

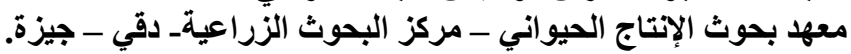

اجري هذا البحث علي الماعز الزر ايبي الحلاب لاختبار تأثير استخدام بذور السيسبان لتحل جزئيا محل بروتين العلف المركز علي التيا

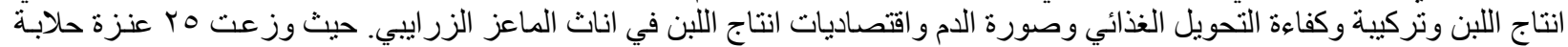

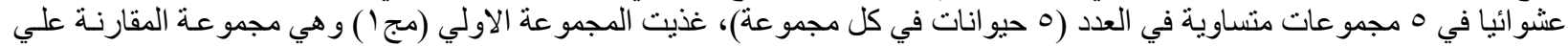

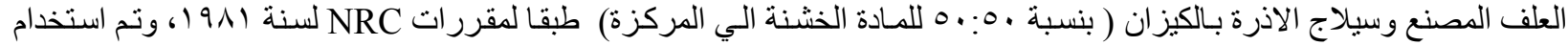

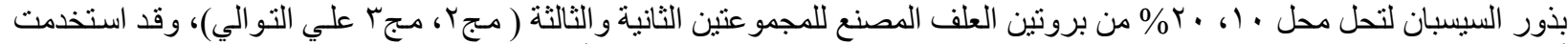

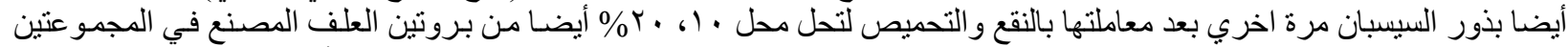

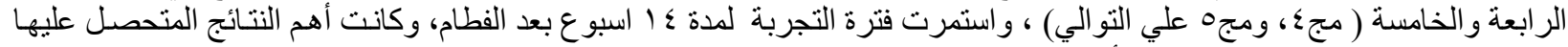

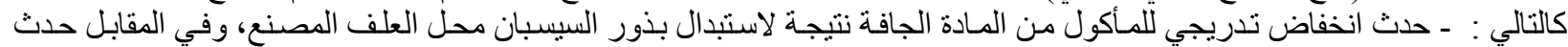

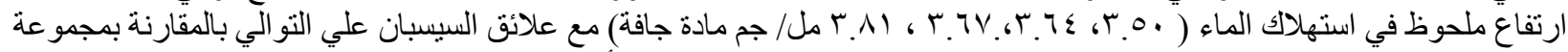

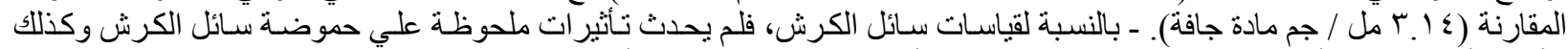

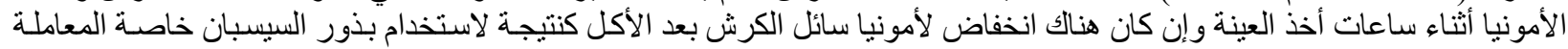

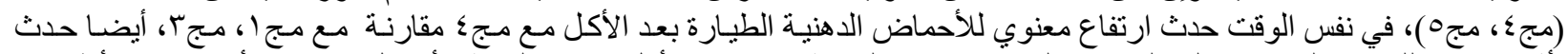

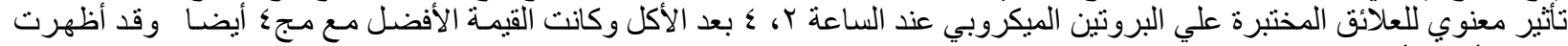

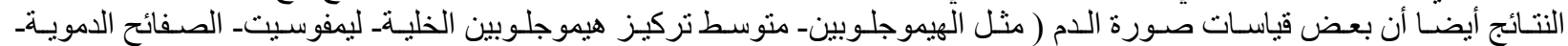

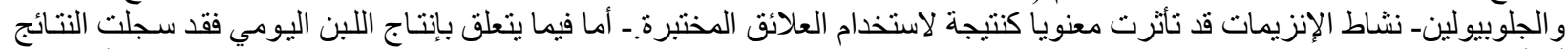

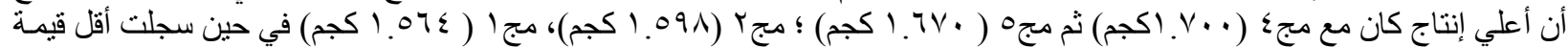

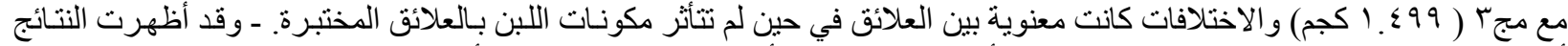

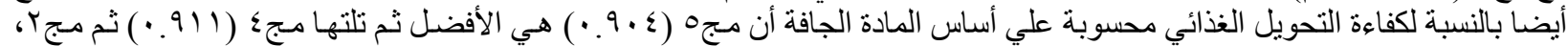

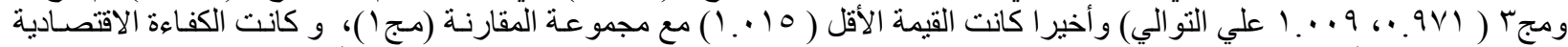

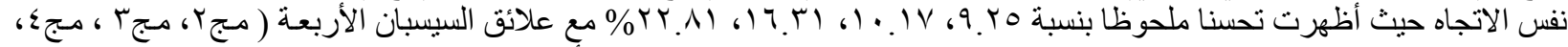

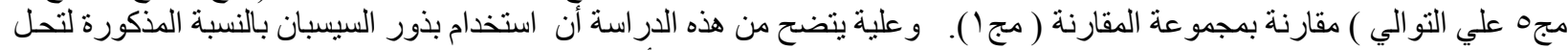

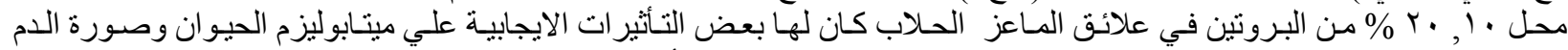

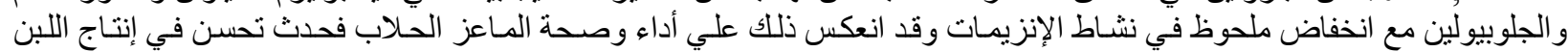

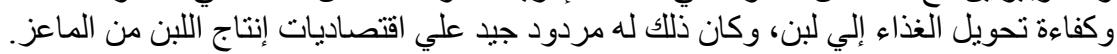

